\title{
In Situ Measurements of Speech Intelligibility in a Private University's Classrooms in Jakarta, Indonesia
}

\author{
Joko Sarwono and Indra Sihar \\ Engineering Physics, InstitutTeknologi Bandung, Jl. Ganesha 10 \\ Bandung, Jawa Barat, Indonesia \\ E-mail: sihar.indra@gmail.com
}

\begin{abstract}
This paper discusses in situ measurements of the speech intelligibility of classrooms in a private university in Jakarta. Seven classrooms with and without stepping students seating area are evaluated. Impulse Response method is used to measure the acoustics condition of the classrooms. Their speech intelligibility level is determined using the reverberation times (T30) and definition (D50) conditions. Results show that all the classrooms have a low frequency reverberation problem. These problems lead to lower their Speech Intelligibility Level. It is also shown that stepping student seating area does not increase speech intelligibility level.
\end{abstract}

Keywords: classroom, speech, intelligibility, seating area.

\section{Introduction}

In a formal education, classroom is the main space for learning and teaching activities. Inside it interactions between student and teacher or among students create an education environment. As an infrastructure for education, good classroom becomes crucial to be built to support learning and teaching activities. One aspect to be concerned to make a good classroom is by creating a good acoustics environment. Frequently, people neglect this aspect which results in many acoustical problems in the classroom. Moreover, poor acoustics environment could make the learning environment less effective or even distracting.

There are many acoustical problems in a classroom; one of them is excessive background noise. This problem could make students prematurely tired, having stress reactions, anxiety, lack of memory, irritation and also wasting their cognitive abilities ${ }^{1,2}$. These effects lead to learning difficulties for the student.

Another problem due to the poor acoustical design is the effect for the teacher. Many times during the lecture, teachers are forced to raise their voice to compensate the poor acoustical conditions ${ }^{3}$. Additionally, according to Tiesler and Oberdorster excessive background noise level in classroom create psycho-physiological stress for the teacher ${ }^{4}$.

All these problems can be summarized to the lack of speech intelligibility. Both excessive background noise and inappropriate room acoustic environment can reduce speech intelligibility. According to Bradley, listeners do not realize that they are having difficulty understanding speech because of their remarkable abilities to guess the correct word in noisy or reverberant conditions. Listeners only aware of more difficult communication situations when the interfering background noise are stops ${ }^{5}$. Considering the problems, it is very important to know acoustical condition in a classroom. The goal of this study is to increase the awareness about importance of classrooms acoustic. This paper is a short report on the in-situ measurement of several classrooms. It is conducted to investigate the speech intelligibility condition. Seven classrooms are divided into two main types, classroom with and without stepping students seating area. The evaluated classrooms belong to one of private university in Jakarta area. 


\section{Measurement Design}

In this paper, speech intelligibility evaluation is conducted by measuring two room acoustic parameters: Reverberation Time (T30) and Definition (D50) in each room. These parameters are derived from Impulse Response (IR) function, which measured by timestretched pulses (TSP) method. TSP method is an indirect measurement method that use time varying frequency signals to get the deconvolved IR function of the room. The two parameters are defined as follows: reverberation time (second) is the time that is required for sound pressure level to decrease by $60 \mathrm{~dB}$, at a rate of decay given by the linear least-squares regression of the measure decay curve form a level $5 \mathrm{~dB}$ below initial level to $35 \mathrm{~dB}$ below.D50 or Definition (\%) is defined as the ratio of early $50 \mathrm{~ms}$ sound energy to the late arriving sound energy such as expressed by following formula:

$$
D_{50}=\frac{\int_{0}^{0.05 s} p^{2}(t) d t}{\int_{0}^{\infty} p^{2}(t) d t} .
$$

\subsection{Measurement Conditions}

Measurements are carried out in each classroom with the capacity of 40-50 seats, the sketch example of classroom can be seen in Fig. 1. In this study, the classrooms are divided into two types of room, which is with and without stepping students seating area (Fig. 2 and 3).

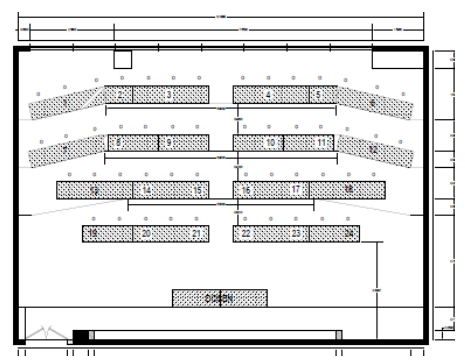

Fig. 1. Sketch of One of Measured Classroom (top view).

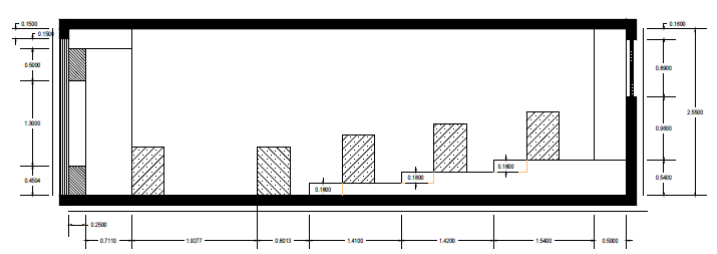

Fig. 2. Classroom with stepping students seating area (side view).

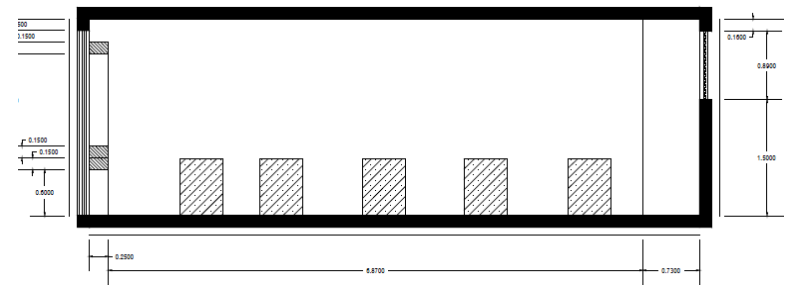

Fig. 3. Classroom without stepping students seating area (side view).

The measurement is conducted in the following condition:

- Two cases of source position are measured. One is located in the teacher position with $1.5 \mathrm{~m}$ height (mimicking standing position); another one is at student position with $1.2 \mathrm{~m}$ height (mimicking student sitting position). These positions are taken into account to mimic the situation in the class.

- 16-25 measurement positions ware distributed around the area of the student positions with $1.2 \mathrm{~m}$ height (mimicking the ear position while sitting). The distance of each microphone position is $>1 \mathrm{~m}$, with the distance to the wall $>1 \mathrm{~m}$.

- Omni directional sound source is used by dodecahedral configuration following the ISO 3382 specification.

- All measurements parameters are calculated for each octave band filters $125 \mathrm{~Hz}-4000 \mathrm{~Hz}$.

- The state of the classroom is unoccupied.

- All the microphones and calibrator used are class-1 types.

The conducted measurement and the picture of the measurement can be seen in Fig. 4.

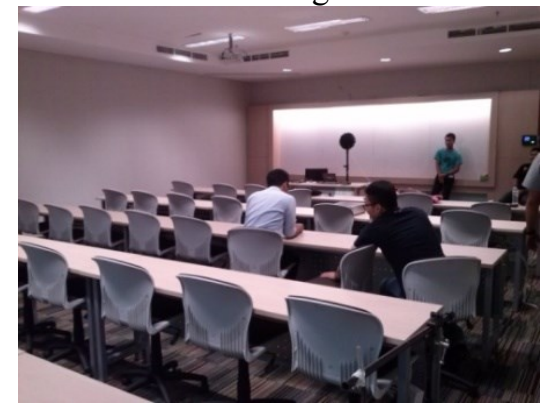

Fig. 4. The measurement set-up and condition.

\subsection{Classroom Specification}

There are two types of classrooms in this measurement, the first is the classroom without stepping students seating area; it consists of: 
- Room 202, 50 seats, Volume: $244 \mathrm{~m}^{3}$.

- Room 2053, 40 seats, Volume: $233 \mathrm{~m}^{3}$

- Room 2501, 46 seats, Volume: $240 \mathrm{~m}^{3}$

The second is the room with stepping students seating area; it consists of:

- Room 101, 50 seats, Volume: $210 \mathrm{~m}^{3}$

- Room 2056, 50 seats, Volume: $216 \mathrm{~m}^{3}$

- Room 1304, 40 seats, Volume: $257 \mathrm{~m}^{3}$

- Room 2105, 50 seats, Volume: $246 \mathrm{~m}^{3}$

\section{Results and Analysis}

The good speech intelligibility criteria are defined as follows: T30 of the classroom between $0.45 \mathrm{~s}-0.7 \mathrm{~s}$, and D50 is more than $50 \%$.

\subsection{Room 202}

In room 202, all frequency range and all cases of the sound source the T30 are high (Table 1). In the case of definition, it is also shown in table 2 that for the case lecturer as sound source almost all frequency has definition problem. It is also can be seen that the distribution of the definition in all direction varies significantly.

Table 1. Reverberation Time of Room 202

\begin{tabular}{|c|c|c|c|c|c|c|c|}
\hline \multirow{2}{*}{ Name } & & \multicolumn{6}{|c|}{ T30(seconds) } \\
\hline & Freq $(\mathrm{Hz})$ & 125 & 250 & 500 & 1000 & 2000 & 4000 \\
\hline \multirow{2}{*}{$\begin{array}{c}\text { Room } 202 \\
\text { Lecturer as } \\
\text { Source }\end{array}$} & Average & 2.0 & 1.4 & 1.3 & 1.1 & 1.0 & 0.9 \\
\hline & $\begin{array}{c}\text { Standard } \\
\text { Deviation }\end{array}$ & 0.2 & 0.2 & 0.1 & 0.1 & 0.0 & 0.0 \\
\hline \multirow{2}{*}{$\begin{array}{l}\text { Room } 202 \\
\text { Student as } \\
\text { Source }\end{array}$} & Average & 2.0 & 1.4 & 1.3 & 1.1 & 1.0 & 0.9 \\
\hline & $\begin{array}{c}\text { Standard } \\
\text { Deviation }\end{array}$ & 0.2 & 0.1 & 0.1 & 0.1 & 0.0 & 0.0 \\
\hline
\end{tabular}

Table 2. Definition of Room 202

\begin{tabular}{|c|c|c|c|c|c|c|c|}
\hline \multirow{2}{*}{ Name } & & \multicolumn{6}{|c|}{ D50 (\%) } \\
\cline { 2 - 8 } & Freq. & 125 & 250 & 500 & 1000 & 2000 & 4000 \\
\hline \multirow{2}{*}{$\begin{array}{c}\text { Room 202 } \\
\text { Lecturer as } \\
\text { Source }\end{array}$} & Average & 31.7 & 49.9 & 39.1 & 48.9 & 49.2 & 55.0 \\
\cline { 2 - 8 } & $\begin{array}{c}\text { Standard } \\
\text { Deviation }\end{array}$ & 11.6 & 9.8 & 9.2 & 6.2 & 5.4 & 4.4 \\
\hline $\begin{array}{c}\text { Room 202 } \\
\text { Student as } \\
\text { Source }\end{array}$ & Average & 25.2 & 44.7 & 46.9 & 51.9 & 52.3 & 61.8 \\
\cline { 2 - 8 } & Standard & 15.1 & 15.3 & 8.8 & 10.3 & 10.3 & 8.5 \\
\hline
\end{tabular}

Table 3. Reverberation Time of Room 2053

\begin{tabular}{|c|c|c|c|c|c|c|c|}
\hline \multirow{2}{*}{ Name } & & \multicolumn{6}{|c|}{ T30 (seconds) } \\
\cline { 2 - 9 } & Freq & 125 & 250 & 500 & 1000 & 2000 & 4000 \\
\hline $\begin{array}{c}\text { Room 2053 } \\
\text { Lecturer as } \\
\text { Source }\end{array}$ & Average & 1.3 & 1.0 & 1.0 & 0.8 & 0.7 & 0.7 \\
\cline { 2 - 8 } & $\begin{array}{c}\text { Standard } \\
\text { Deviation }\end{array}$ & 0.1 & 0.1 & 0.1 & 0.0 & 0.0 & 0.0 \\
\hline $\begin{array}{c}\text { Room 2053 } \\
\text { Student as } \\
\text { Source }\end{array}$ & Average & 1.3 & 1.0 & 1.0 & 0.8 & 0.7 & 0.7 \\
\cline { 2 - 9 } & $\begin{array}{c}\text { Standard } \\
\text { Deviation }\end{array}$ & 0.1 & 0.1 & 0.1 & 0.0 & 0.0 & 0.0 \\
\hline
\end{tabular}

Table 4. Definition of Room 2053

\begin{tabular}{|c|c|c|c|c|c|c|c|}
\hline \multirow{2}{*}{ Name } & & \multicolumn{6}{|c|}{ D50 (\%) } \\
\cline { 2 - 8 } & Freq & 125 & 250 & 500 & 1000 & 2000 & 4000 \\
\hline $\begin{array}{c}\text { Room 2053 } \\
\text { Lecturer as } \\
\text { Source }\end{array}$ & Average & 44.2 & 54.9 & 55.4 & 60.3 & 61.6 & 67.4 \\
\cline { 2 - 8 } & $\begin{array}{c}\text { Standard } \\
\text { Deviation }\end{array}$ & 18.5 & 11 & 10.7 & 7.5 & 7.6 & 4.8 \\
\hline Room 2053 & Average & 58 & 54.8 & 54.5 & 62.3 & 63.7 & 69 \\
\cline { 2 - 8 } $\begin{array}{c}\text { Student as } \\
\text { Source }\end{array}$ & $\begin{array}{c}\text { Standard } \\
\text { Deviation }\end{array}$ & 18 & 15.6 & 10.4 & 10.8 & 8.7 & 7.2 \\
\hline
\end{tabular}

\subsection{Room 2053}

From Table 3 and 4, it is shown that reverberation time and definition in range $1000 \mathrm{~Hz}-4000 \mathrm{~Hz}$ has already meet the requirement for a good speech condition, with one exception though T30 in $1000 \mathrm{~Hz}$, where the value is a little bit higher from the required number. In frequency range below $1000 \mathrm{~Hz}$, it can be seen that reverberation time are high, and then from the definition parameter, the spatial distribution is poor, the deviation can be $10-20 \%$.

Table 5. Reverberation Time of Room 2501

\begin{tabular}{|c|c|c|c|c|c|c|c|}
\hline \multirow{2}{*}{ Name } & & \multicolumn{6}{|c|}{ T30 (seconds) } \\
\cline { 2 - 8 } & Freq. & 125 & 250 & 500 & 1000 & 2000 & 4000 \\
\hline Room 2501 & Average & 0.8 & 0.8 & 0.9 & 0.9 & 0.9 & 0.8 \\
\cline { 2 - 8 } $\begin{array}{c}\text { Lecturer as } \\
\text { Source }\end{array}$ & $\begin{array}{c}\text { Standard } \\
\text { Deviation }\end{array}$ & 0.6 & 0.1 & 0.1 & 0.0 & 0.0 & 0.0 \\
\hline $\begin{array}{c}\text { Room 2501 } \\
\text { Student as } \\
\text { Source }\end{array}$ & Average & 0.6 & 0.8 & 0.9 & 0.9 & 0.9 & 0.8 \\
\cline { 2 - 8 } & $\begin{array}{c}\text { Standard } \\
\text { Deviation }\end{array}$ & 0.1 & 0.1 & 0.1 & 0.0 & 0.1 & 0.0 \\
\hline
\end{tabular}


Table 6. Definition of Room 2501

\begin{tabular}{|c|c|c|c|c|c|c|c|}
\hline \multirow{2}{*}{ Name } & & \multicolumn{6}{|c|}{ D50 (\%) } \\
\hline & Freq. & 125 & 250 & 500 & 1000 & 2000 & 4000 \\
\hline \multirow{2}{*}{$\begin{array}{c}\text { Room } 2501 \\
\text { Lecturer as } \\
\text { Source }\end{array}$} & Average & 67 & 55.4 & 54.2 & 56.2 & 62.2 & 71.6 \\
\hline & $\begin{array}{c}\text { Standard } \\
\text { Deviation }\end{array}$ & 16.2 & 13.6 & 12.1 & 12.7 & 10 & 8.4 \\
\hline \multirow{2}{*}{$\begin{array}{c}\text { Room } 2501 \\
\text { Student as } \\
\text { Source }\end{array}$} & Average & 68.5 & 61 & 55.5 & 56.5 & 62.2 & 70.3 \\
\hline & $\begin{array}{c}\text { Standard } \\
\text { Deviation }\end{array}$ & 15.5 & 14.9 & 11.5 & 7.8 & 7.7 & 4.9 \\
\hline
\end{tabular}

\subsection{Room 2501}

From table 5, it is shown that all the reverberation time do not meet the requirement for a good speech intelligibility. Meanwhile in table 6 , it is shown that averagely definition parameters are good, but poor spatial distribution of definition happens at region 125 Hz- $1000 \mathrm{~Hz}$.

\subsection{Room 101}

At room 101, from table 7 , it is shown that all the reverberation time does not meet the requirement for good speech intelligibility. From table 8 , it is also can be derived that poor definition at frequency $125-500 \mathrm{~Hz}$ happens. The poor definition can be seen either from the average value and also spatial deviation of the value.

Table 7. Reverberation Time of Room 101

\begin{tabular}{|c|c|c|c|c|c|c|c|}
\hline \multirow{2}{*}{ Name } & & \multicolumn{6}{|c|}{ T30 (seconds) } \\
\cline { 2 - 8 } & Freq. & 125 & 250 & 500 & 1000 & 2000 & 4000 \\
\hline $\begin{array}{c}\text { Room 101 } \\
\text { Lecturer as } \\
\text { Source }\end{array}$ & Average & 1.6 & 1.3 & 1.2 & 1.0 & 0.9 & 0.8 \\
\cline { 2 - 8 } & $\begin{array}{c}\text { Standard } \\
\text { Deviation }\end{array}$ & 0.2 & 0.1 & 0.1 & 0.0 & 0.0 & 0.0 \\
\hline $\begin{array}{c}\text { Room 101 } \\
\text { Student as } \\
\text { Source }\end{array}$ & Average & 1.3 & 1.3 & 1.2 & 1.0 & 0.9 & 0.8 \\
\cline { 2 - 8 } & Standard & 0.2 & 0.1 & 0.1 & 0.0 & 0.0 & 0.0 \\
\hline
\end{tabular}

Table 8. Definition of Room 101

\begin{tabular}{|c|c|c|c|c|c|c|c|}
\hline \multirow{2}{*}{ Name } & & \multicolumn{6}{|c|}{ D50 (\%) } \\
\cline { 2 - 8 } & Freq. & 125 & 250 & 500 & 1000 & 2000 & 4000 \\
\hline $\begin{array}{c}\text { Room 101 } \\
\text { Lecturer as } \\
\text { Source }\end{array}$ & Average & 45.2 & 54.1 & 48.2 & 54.3 & 57.1 & 65.4 \\
\cline { 2 - 8 } & $\begin{array}{c}\text { Standard } \\
\text { Deviation }\end{array}$ & 16.5 & 9 & 7.5 & 5.7 & 6.1 & 5.4 \\
\hline $\begin{array}{c}\text { Room 101 } \\
\text { Student as } \\
\text { Source }\end{array}$ & Average & 43.4 & 48.4 & 47.2 & 56 & 57.7 & 64.6 \\
\cline { 2 - 8 } & Standard & 18.5 & 16.9 & 10.9 & 10.8 & 7.6 & 8.6 \\
\hline
\end{tabular}

\subsection{Room 2056}

Table 9. Reverberation Time of Room 2056

\begin{tabular}{|c|c|c|c|c|c|c|c|}
\hline \multirow{2}{*}{ Name } & & \multicolumn{6}{|c|}{ T30 (seconds) } \\
\cline { 2 - 9 } & Freq. & 125 & 250 & 500 & 1000 & 2000 & 4000 \\
\hline $\begin{array}{c}\text { Room 2056 } \\
\text { Lecturer as } \\
\text { Source }\end{array}$ & Average & 1.4 & 1.2 & 1.2 & 0.9 & 0.8 & 0.7 \\
\cline { 2 - 8 } & $\begin{array}{c}\text { Standard } \\
\text { Deviation }\end{array}$ & 0.2 & 0.1 & 0.1 & 0.1 & 0.0 & 0.0 \\
\hline $\begin{array}{c}\text { Room 2056 } \\
\text { Student as } \\
\text { Source }\end{array}$ & Average & 1.3 & 1.2 & 1.2 & 0.9 & 0.8 & 0.7 \\
\cline { 2 - 8 } & $\begin{array}{c}\text { Standard } \\
\text { Deviation }\end{array}$ & 0.2 & 0.1 & 0.1 & 0.0 & 0.0 & 0.0 \\
\hline
\end{tabular}

From table 9, it is shown that only one band frequency $(4000 \mathrm{~Hz})$ has proper reverberation time for good speech intelligibility. From Table 10, it is shown that definition for frequency $125 \mathrm{~Hz}-1000 \mathrm{~Hz}$ are not good for speech intelligibility of the classroom; it is neither from the distribution of the definition or from the average measured value.

Table 10. Definition of Room 2056

\begin{tabular}{|c|c|c|c|c|c|c|c|}
\hline \multirow{2}{*}{ Name } & & \multicolumn{6}{|c|}{ D50 (\%) } \\
\hline & Freq. & 125 & 250 & 500 & 1000 & 2000 & 4000 \\
\hline \multirow{2}{*}{$\begin{array}{c}\text { Room } 2056 \\
\text { Lecturer as } \\
\text { Source }\end{array}$} & Average & 43.3 & 46.5 & 47.7 & 52 & 57.8 & 67 \\
\hline & $\begin{array}{c}\text { Standard } \\
\text { Deviation }\end{array}$ & 12.8 & 11.8 & 10 & 7.7 & 7.5 & 4.8 \\
\hline \multirow{2}{*}{$\begin{array}{c}\text { Room } 2056 \\
\text { Student as } \\
\text { Source }\end{array}$} & Aver & 41.8 & 44.3 & 46.5 & 55.3 & 61.9 & 69. \\
\hline & $\begin{array}{c}\text { Standard } \\
\text { Deviation }\end{array}$ & 19.6 & 13.6 & 13.1 & 12.3 & 8.2 & 6.6 \\
\hline
\end{tabular}

\subsection{Room 1304}

Table. 11 Reverberation Time of Room 1304

\begin{tabular}{|c|c|c|c|c|c|c|c|}
\hline \multirow{2}{*}{ Name } & & \multicolumn{6}{|c|}{ T30 (seconds) } \\
\cline { 2 - 8 } & Freq. & 125 & 250 & 500 & 1000 & 2000 & 4000 \\
\hline $\begin{array}{c}\text { Room 1304 } \\
\text { Lecturer as } \\
\text { Source }\end{array}$ & Average & 0.9 & 0.7 & 0.7 & 0.7 & 0.6 & 0.6 \\
\cline { 2 - 8 } & $\begin{array}{c}\text { Standard } \\
\text { Deviation }\end{array}$ & 0.9 & 0.2 & 0.2 & 0.1 & 0.1 & 0.1 \\
\hline $\begin{array}{c}\text { Room 1304 } \\
\text { Student as } \\
\text { Source }\end{array}$ & Average & 0.7 & 0.6 & 0.6 & 0.7 & 0.6 & 0.6 \\
\cline { 2 - 8 } & $\begin{array}{c}\text { Standard } \\
\text { Deviation }\end{array}$ & 0.6 & 0.1 & 0.1 & 0.0 & 0.0 & 0.0 \\
\hline
\end{tabular}


Table 12. Definition of Room 1304

\begin{tabular}{|c|c|c|c|c|c|c|c|}
\hline \multirow{2}{*}{ Name } & & \multicolumn{6}{|c|}{ D50 (\%) } \\
\cline { 2 - 8 } & Freq & 125 & 250 & 500 & 1000 & 2000 & 4000 \\
\hline \multirow{2}{*}{$\begin{array}{c}\text { Room 1304 } \\
\text { Lecturer as } \\
\text { Source }\end{array}$} & Average & 65.9 & 64.1 & 66.6 & 64.8 & 68.5 & 75.2 \\
\cline { 2 - 8 } & $\begin{array}{c}\text { Standard } \\
\text { Deviation }\end{array}$ & 23 & 16.2 & 8.3 & 7.5 & 6.5 & 4.4 \\
\hline $\begin{array}{c}\text { Room 1304 } \\
\text { Student as } \\
\text { Source }\end{array}$ & Average & 65.1 & 63.8 & 68.6 & 69.3 & 74.1 & 74.9 \\
\cline { 2 - 8 } & $\begin{array}{c}\text { Standard } \\
\text { Deviation }\end{array}$ & 15.5 & 12.9 & 13.6 & 9.8 & 5.2 & 6.3 \\
\hline
\end{tabular}

From table 11, it can be seen that the reverberation time of this room can deliver good speech intelligibility except in very low frequency $(125 \mathrm{~Hz})$. The spatial distribution is not well enough especially in band frequency $125 \mathrm{~Hz}-500 \mathrm{~Hz}$. From table 12, the definition are enough to deliver a good speech intelligibility, but the raised problem in this room, is on the spatial distribution of low frequency $(125 \mathrm{~Hz}-500 \mathrm{~Hz})$ where it can be seen can be varying $10-23 \%$.

\subsection{Room 2105}

Table 13. Reverberation Time of Room 2105

\begin{tabular}{|c|c|c|c|c|c|c|c|}
\hline \multirow{2}{*}{ Name } & & \multicolumn{6}{|c|}{ T30 (seconds) } \\
\cline { 2 - 8 } & Freq. & 125 & 250 & 500 & 1000 & 2000 & 4000 \\
\hline $\begin{array}{c}\text { Room 2105 } \\
\text { Lecturer a } \\
\text { Source }\end{array}$ & Average & 1.0 & 1.0 & 0.9 & 0.8 & 0.7 & 0.6 \\
\cline { 2 - 8 } & $\begin{array}{c}\text { Standard } \\
\text { Deviation }\end{array}$ & 0.1 & 0.1 & 0.1 & 0.0 & 0.0 & 0.0 \\
\hline $\begin{array}{c}\text { Room 2105 } \\
\text { Student as } \\
\text { Source }\end{array}$ & Average & 1.0 & 1.0 & 1.0 & 0.9 & 0.7 & 0.7 \\
\cline { 2 - 8 } & Standard & 0.1 & 0.1 & 0.1 & 0.1 & 0.0 & 0.0 \\
\hline
\end{tabular}

Table 14. Definition of Room 2105

\begin{tabular}{|c|c|c|c|c|c|c|c|}
\hline \multirow{2}{*}{ Name } & & \multicolumn{6}{|c|}{ D50 (\%) } \\
\hline & Freq & 125 & 250 & 500 & 1000 & 2000 & 4000 \\
\hline \multirow{2}{*}{$\begin{array}{c}\text { Room } 2105 \\
\text { Lecturer as } \\
\text { Source }\end{array}$} & Average & 54 & 52.4 & 57.1 & 59.5 & 63.7 & 66.8 \\
\hline & $\begin{array}{c}\text { Standard } \\
\text { Deviation }\end{array}$ & 17.2 & 11 & 8.5 & 7.4 & 7.1 & 5.6 \\
\hline \multirow{2}{*}{$\begin{array}{c}\text { Room } 2105 \\
\text { Student as } \\
\text { Source }\end{array}$} & Averag & 65.9 & 60.1 & 58.6 & 57.6 & 64.4 & 70.5 \\
\hline & $\begin{array}{c}\text { Standard } \\
\text { Deviation }\end{array}$ & 12.9 & 14.5 & 12.4 & 10.6 & 8.6 & 8 \\
\hline
\end{tabular}

Table 3 shows that reverberation time values below $1000 \mathrm{~Hz}$ do not deliver good speech intelligibility. On the other side, from table 14, it is shown that averagely the room can deliver good speech intelligibility, but the poor spatial distribution still happens in frequency below $1000 \mathrm{~Hz}$.

\section{Conclusions and Further Works}

From the results, it could be concluded that all the rooms except one out of the seven classrooms are not adequate for the learning and teaching activity. It is also concluded that the stepping student area does not enhance the quality of speech intelligibility, as almost all classrooms have poor reverberation time and definition. From the definition parameter, it is also shown that all classrooms have diffuseness problem in frequency band below $1000 \mathrm{~Hz}$, while the reverberation time has a good distribution, spatially. This means that the later reverberation of the sound energy is still dominant compared to the direct energy. Further works should be focused on the coherency of signals that arrived in the students seating area. This is also important to evaluate the diffusivity of sound inside the classroom. Furthermore, more parameters could be included to evaluate the speech intelligibility, such as insulation performance, background noise, and also speech transmission indexes.

\section{References}

1. Henrique P., Zannin T., Petri D., Zwirtes Z., Evaluation of the acoustic performance of classrooms in public schools, Applied Acoustics 70 (2009) 626-635.

2. Melo V.S.G, Tenenbaum R.A., Musafir R.E., Intelligibility assesment in elementary school classrooms from binaural room impulse responses measured with a childlike dummy head, Applied Acoustics 74 (2013) 1436-1447.

3. Han N., Mak C.M., Improving speech intelligibility in classrooms through the mirror image model, Applied Acoustics 69 (2008) 945-950.

4. Tiesler G., Oberdorster M, Noise - a stress factor? acoustic ergonomics of schools, Euronoise 2006, Tampere, Finland.

5. Bradley J. S., Acoustical design of rooms for speech, Construction Technology Update No. 51, 2002, National Research Council of Canada. 